\title{
Posterior segment intraocular foreign bodies: the effect of weight and size, early versus late vitrectomy and outcomes
}

\author{
Zafer Öztaş, M.D.,, Serhad Nalçacı, M.D., ${ }^{1}$ Filiz Afrashi, M.D.,, ${ }^{1}$ Tansu Erakgün, M.D., ${ }^{2}$ \\ Jale Menteş, M.D., ${ }^{1}$ Cumali Değirmenci, M.D., ${ }^{1}$ Cezmi Akkın, M.D. ${ }^{1}$
}

${ }^{1}$ Department of Ophthalmology, Ege University Faculty of Medicine, Izmir

${ }^{2}$ Department of Ophthalmology, Ekol ENT Hospital, Izmir

\begin{abstract}
BACKGROUND: The objective of this study was to identify the effects of weight and size characteristics of posterior segment intraocular foreign bodies (IOFBs) in open globe injuries.

METHODS: Fifty-eight eyes of 58 patients with posterior segment IOFBs were enrolled in the study. All IOFBs were removed by pars plana vitrectomy. Factors including age, gender, best corrected visual acuity (BCVA), nature of IOFBs, weight and dimensions of IOFBs, initial ocular features, timing of IOFB removal, entry site of IOFBs, interventions and complications were evaluated.

RESULTS: Mean age of the patients was $32.7 \pm \mid 4.2$ years, and mean follow up period was $18 \pm 13.3$ months. Weight, length, width and thickness of IOFBs were found negatively correlated with initial and final BCVA levels $(p<0.05)$. Weight of IOFBs was significantly greater in eyes with initial hyphema, vitreous hemorrhage, retinal hemorrhage, retinal detachment, and uveal prolapse $(p<0.05)$. Width and thickness of IOFBs were significantly greater in eyes with hyphema, vitreous hemorrhage, retinal hemorrhage and uveal prolapse $(p<0.05)$. Length of IOFBs was significantly longer in eyes with hyphema $(p<0.05)$. Presence of initial or subsequent retinal detachment was associated with poor final BCVA $(p<0.05)$. There was no association between the timing of IOFB removal and incidence of endophthalmitis.
\end{abstract}

CONCLUSION: Greater weight and size of posterior segment IOFBs were associated with worse outcomes in open globe injuries. Protective eyewear has a crucial importance to avoid work-related injuries. In our study, early or late vitrectomy for an IOFB removal had no significant effect on anatomic and visual outcomes. Therefore, vitrectomy can be postponed until optimal conditions are obtained.

Key words: Endophthalmitis; intraocular foreign bodies; pars plana vitrectomy; retinal detachment.

\section{INTRODUCTION}

Ocular injuries with posterior segment intraocular foreign bodies (IOFBs) remain a major cause of ocular morbidity. ${ }^{[1,2]}$ Retained IOFBs may lead to sight-threatening conditions, such as endophthalmitis, retinal breaks, retinal detachment, vitreous hemorrhage, and macular scar formation. The severity of injury caused by an IOFB depends on several factors, including characteristics of the foreign body, momentum of

Address for correspondence: Zafer Öztaş, M.D.

Ege Üniversitesi Tıp Fakültesi, Göz Hastalıkları Anabilim Dalı,

3. Kat, Bornova, 35040 İzmir, Turkey

Tel: +90 232 - 3903788 E-mail: zaferdr2000@gmail.com

Qucik Response Code Ulus Travma Acil Cerrahi Derg

2015;2I(6):496-502

doi: $10.5505 /$ tjtes. 2015.03608

Copyright 2015

TJTES the object, presence of endophthalmitis, and the entry site of penetration. ${ }^{[3]}$ Removal of posterior segment IOFBs by pars plana vitrectomy (PPV) is the main surgical procedure that provides direct viewing and controlled surgery.

The purpose of this study was to identify the impact of weight and size characteristics of posterior segment IOFBs in open globe injuries. To the best of our knowledge, this is the first study that correlates (Spearman) weight and size measurements of posterior segment IOFBs with presenting and final visual acuity levels. Prognostic factors for presenting and final visual acuity, management, and outcomes were also evaluated.

\section{MATERIALS AND METHODS}

A retrospective chart review was approved by appropriate institutional ethics committees and health authorities and was conducted in accordance with the Declaration of Helsinki. Consecutive medical records of patients with posterior segment IOFBs who presented at our hospital between October 
2005 and January 2013 were identified. Fifty-eight patients were enrolled for a total of 58 eyes. Of the sixty-five patients diagnosed with posterior segment IOFBs, seven were excluded because of multiple IOFBs. Anterior segment IOFBs were also excluded.

The data collected included age, gender, initial and final best corrected visual acuity (BCVA), weight and dimensions (length, width, thickness) of IOFBs, nature of IOFBs, initial ocular features, time of interval from injury to IOFB removal, entry site of IOFBs, location of IOFBs, interventions, and complications.

Visual acuity was measured with the Snellen decimal system used in our office. Visual acuity values were converted to logMAR units for statistical analysis. All foreign bodies removed from the eyes were packaged immediately following removal and kept in our clinic for medicolegal reasons. IOFBs were measured with a caliper to determine the greatest diameter in length, width, and thickness. Weights of IOFBs were measured in the laboratory using a precision weighing device.

All eyes underwent IOFB removal with a standard three-port PPV technique. Patients who had a leaking wound underwent primary globe repair prior to PPV. In suitable cases, primary globe repair was combined with PPV. Patients with a selfsealing wound without leakage had PPV as initial intervention. IOFBs were removed through the sclera or anterior segment depending on their characteristics.

Birmingham Eye Trauma Terminology was used for classification and definition of ocular trauma. ${ }^{[4]}$ Open globe injury indicates a full thickness wound of the eye. An IOFB indicates any open globe injury with a retained foreign body. A selfsealing wound is an entry site of the IOFB that closes tightly without primary globe repair. Ocular Trauma Classification Group was used to describe wound location:[5] Zone I injury involves the cornea and limbus; zone 2 injury involves the region $5 \mathrm{~mm}$ or less posterior to the limbus; and zone 3 involves the region exceeding $5 \mathrm{~mm}$ posterior to the limbus. Analysis was performed using SPSS software version 16.0 (SPSS, Inc., Chicago, Illinois, USA). After the test of normality, nonparametric tests were used for statistical analysis. Association between the variables was studied using the Mann-Whitney $U$ and Pearson chi-square tests. Continuous variables were compared with Spearman's rho. A $p$ value of less than 0.05 was considered statistically significant for all tests.

\section{RESULTS}

Fifty-eight eyes of 58 patients (53 male, 5 female; mean age, $32.7 \pm 14.2$ [range, 8-78] years) with posterior segment IOFBs were included into the study. Mean follow-up was $17.9 \pm 13.3$ (range, 3-60) months. The causes of posterior segment IOFBs were work-related open globe injuries in thirty-nine eyes $(67 \%)$, nonwork-related trauma in eight eyes (14\%), gun shot in four eyes (7\%), and unknown in seven eyes (12\%). The majority of IOFBs were metal in fifty-two eyes ( $90 \%)$, stone in three eyes (5\%), glass in two eyes $(3 \%)$, and animal horn in one eye (2\%). Table I presents initial findings identified in patients with posterior segment IOFBs. In four cases, iris and lens injuries were not assessed initially due to total hyphema. IOFBs were localized to the retinal surface in forty-one eyes $(70.7 \%)$ and to the vitreous in seventeen eyes (29.3\%). IOFB entry points involved zone I in forty-one eyes (70.7\%), zone 2 in sixteen eyes (27.6\%), and zone 3 in one eye (1.7\%). For surgical management, primary globe repair was performed prior to removal of the IOFB in I sixteen eyes $(27.6 \%)$, and primary globe repair combined with PPV as a single procedure was used in twenty-four eyes (4I.4\%). PPV without primary globe repair was used for patients with a self-sealing wound ( 18 eyes [3I\%]). IOFBs were removed through the sclera in forty-eight eyes (82.8\%) and through the anterior segment (trans-corneal) in ten eyes ( $17.2 \%)$. We used silicone oil tamponade in forty-five eyes $(77.6 \%)$ and gas tamponade in nine eyes (15.5\%). At the end of the follow-up, crystalline lens was preserved in thirteen eyes (22.4\%). Procedures resulted in pseudophakia in forty-one eyes (70.7\%) and aphakia in four eyes $(6.9 \%)$. The most frequent complication after the removal of IOFBs was retinal detachment in eleven eyes (I8.9\%). Retinal detachment occurred subsequently in eight eyes and re-detached in three eyes. Other complications were glaucoma in ten eyes (17.2\%), macular scar formation in four eyes (6.9\%), aphakia in four eyes $(6.9 \%)$, corneal decompensation and scars in four eyes (6.9\%), and phthisis bulbi in two eyes (3.4\%).

Mean weight of IOFBs was 46ะ I 16 mg (range, 0. I-806; median, 10). Mean measurements of length, width, and thickness of the IOFBs were $3.65 \pm 3.45 \mathrm{~mm}$ (range, 0.8-19.7; median, 2.6), $2.08 \pm \mathrm{I} .5 \mathrm{I} \mathrm{mm}$ (range, 0.5-8.5; median, I.8), and 0.89 \pm 0.66 $\mathrm{mm}$ (range, 0.2-2.6; median, 0.7), respectively. The relation between size of IOFBs and IOFB localization, removal site of

Table I. Initial findings of the patients

\begin{tabular}{llc}
\hline Initial findings & \multicolumn{2}{c}{ Number of eyes } \\
\cline { 2 - 3 } & $\mathbf{n}$ & $\%$ \\
\hline Vitreous hemorrhage & 33 & 56.9 \\
Iris injury & 31 & 53.4 \\
Retinal hemorrhage & 29 & 50.0 \\
Lens injury & 26 & 44.8 \\
Retinal break & 25 & 43.1 \\
Hyphema & 20 & 34.5 \\
Uveal prolapse & 13 & 22.4 \\
Endophthalmitis & 9 & 15.5 \\
Retinal detachment & 7 & 12.0 \\
\hline
\end{tabular}


Table 2. Relation between predictive factors and size of intraocular foreign bodies

\begin{tabular}{|c|c|c|c|c|}
\hline & $\begin{array}{l}\text { Mean Weight-mg } \\
\text { (range, median) }\end{array}$ & $\begin{array}{l}\text { Mean Length-mm } \\
\text { (range, median) }\end{array}$ & $\begin{array}{r}\text { Mean Width-mm } \\
\text { (range, median) }\end{array}$ & $\begin{array}{l}\text { Mean Thickness-mm } \\
\text { (range, median) }\end{array}$ \\
\hline \multicolumn{5}{|l|}{ Localization of IOFBs } \\
\hline Vitreous & $\begin{array}{c}36 \pm 53 \\
(0.1-226,14.2)\end{array}$ & $\begin{array}{c}3.8 \pm 3.3 \\
(0.8-15,2.7)\end{array}$ & $\begin{array}{c}2.2 \pm 1.7 \\
(0.5-8.5,2.7)\end{array}$ & $\begin{array}{c}0.9 \pm 0.6 \\
(0.2-2.6,0.8)\end{array}$ \\
\hline Retina & $\begin{array}{c}55 \pm 152 \\
(0.2-80,9.5)\end{array}$ & $\begin{array}{c}3.5 \pm 3.6 \\
(1.5-19.7,2.6)\end{array}$ & $\begin{array}{c}2 \pm 1.3 \\
(0.7-7.5,2)\end{array}$ & $\begin{array}{c}0.9 \pm 0.7 \\
(0.2-2.6,0.6)\end{array}$ \\
\hline \multicolumn{5}{|l|}{ Removal site } \\
\hline Sclera & $\begin{array}{c}42 \pm 122 \\
(0.1-806,9.4)\end{array}$ & $\begin{array}{c}3.5 \pm 3.4 \\
(0.8-19.7,2.5)\end{array}$ & $\begin{array}{c}2 \pm 1.3 \\
(0.5-7.5,1.8)\end{array}$ & $\begin{array}{c}0.8 \pm 0.6 \\
(0.2-2.6,2.7)\end{array}$ \\
\hline Trans-corneal & $\begin{array}{c}66 \pm 88 \\
(2-226,23.2)\end{array}$ & $\begin{array}{c}4.3 \pm 3.9 \\
(1.5-15,3.2)\end{array}$ & $\begin{array}{c}2.6 \pm 2.2 \\
(0.7-8.5,1.8)\end{array}$ & $\begin{array}{c}1.2 \pm 0.7 \\
(0.5-2.6,2.7)^{*}\end{array}$ \\
\hline \multicolumn{5}{|l|}{ Initial lindings } \\
\hline Endophthalmitis (+) & $\begin{array}{c}22 \pm 23 \\
(I-70,9.4)\end{array}$ & $\begin{array}{c}4.0 \pm 2.7 \\
(2-10.5,3)\end{array}$ & $\begin{array}{c}2 \pm 1.2 \\
(0.7-4.8,1.8)\end{array}$ & $\begin{array}{c}0.7 \pm 0.3 \\
(0.2-1.2,0.7)\end{array}$ \\
\hline Endophthalmitis (-) & $\begin{array}{c}51 \pm 126 \\
(0.1-806,9.6)\end{array}$ & $\begin{array}{c}3.6 \pm 3.6 \\
(0.8-19.7,2.6)\end{array}$ & $\begin{array}{c}2.1 \pm 1.6 \\
(0.5-8.5,1.8)\end{array}$ & $\begin{array}{c}0.9 \pm 0.7 \\
(0.2-2.6,0.7)\end{array}$ \\
\hline Iris injury $(+)$ & $\begin{array}{c}28 \pm 47 \\
(0 . I-2 \mid 3,8.3)\end{array}$ & $\begin{array}{c}2.7 \pm 1.3 \\
(0.8-6.3,2.5)\end{array}$ & $\begin{array}{c}\mid .8 \pm 1 \\
(0.5-4.8,1.6)\end{array}$ & $\begin{array}{c}0.8 \pm 0.6 \\
(0.2-2.6,0.6)\end{array}$ \\
\hline Iris injury $(-)$ & $\begin{array}{c}69 \pm 171 \\
(0.2-806,12)\end{array}$ & $\begin{array}{c}4.7 \pm 4.8 \\
(1.1-19.7,2.9)\end{array}$ & $\begin{array}{c}2.4 \pm 1.9 \\
(0.7-8.5,1.9)\end{array}$ & $\begin{array}{c}0.9 \pm 0.6 \\
(0.3-2.6,0.7)\end{array}$ \\
\hline Lens injury $(+)$ & $\begin{array}{c}37 \pm 6 \mid \\
(I-226, I I .2)\end{array}$ & $\begin{array}{c}3.5 \pm 3 \\
(1.1-15,2.5)\end{array}$ & $\begin{array}{c}2 \pm 1.5 \\
(0.7-8.5,1.8)\end{array}$ & $\begin{array}{c}0.9 \pm 0.6 \\
(0.2-2.6,0.6)\end{array}$ \\
\hline Lens injury $(-)$ & $\begin{array}{c}54 \pm 157 \\
(0.1-806,8)\end{array}$ & $\begin{array}{c}3.5 \pm 3.9 \\
(0.8-19.7,2.6)\end{array}$ & $\begin{array}{c}1.9 \pm 1.4 \\
(0.5-7.5,1.8)\end{array}$ & $\begin{array}{c}0.9 \pm 0.7 \\
(0.2-2.6,0.6)\end{array}$ \\
\hline Hyphema (+) & $\begin{array}{c}49 \pm 54 \\
(3-213,28.8)^{*}\end{array}$ & $\begin{array}{c}3.7 \pm 1.9 \\
(1.8-9.5,3.5)^{*}\end{array}$ & $\begin{array}{c}2.4 \pm 1 \\
(0.7-5,2.1)^{*}\end{array}$ & $\begin{array}{c}1.3 \pm 0.7 \\
(0.4-2.6,1)^{*}\end{array}$ \\
\hline Hyphema (-) & $\begin{array}{c}45 \pm 139 \\
(0.1-806,5.6)\end{array}$ & $\begin{array}{c}3.6 \pm 4 \\
(0.8-19.7,2.5)\end{array}$ & $\begin{array}{c}1.9 \pm 1.7 \\
(0.5-8.5,1.5)\end{array}$ & $\begin{array}{c}0.7 \pm 0.5 \\
(0.2-2.6,0.5)\end{array}$ \\
\hline Vitreous hemorrhage $(+)$ & $\begin{array}{c}67 \pm 149 \\
(2-806,16)^{*}\end{array}$ & $\begin{array}{c}4 \pm 4 \\
(1.5-19.7,2.5)\end{array}$ & $\begin{array}{c}2.4 \pm 1.7 \\
(0.7-8.5,2)^{*}\end{array}$ & $\begin{array}{c}I \pm 0.7 \\
(0.4-2.6,0.8)^{*}\end{array}$ \\
\hline Vitreous hemorrhage $(-)$ & $\begin{array}{c}19 \pm 34 \\
(0.1-138,5.8)\end{array}$ & $\begin{array}{c}3.2 \pm 2.4 \\
(0.8-10.5,2.7)\end{array}$ & $\begin{array}{c}1.9 \pm 1.7 \\
(0.5-5,1.5)\end{array}$ & $\begin{array}{c}0.7 \pm 0.5 \\
(0.2-2.6,0.5)\end{array}$ \\
\hline Retinal hemorrhage $(+)$ & $\begin{array}{c}72 \pm 16 \\
(2-806,16)^{*}\end{array}$ & $\begin{array}{c}4 \pm 4.3 \\
(1.5-19.7,2.5)\end{array}$ & $\begin{array}{c}2.4 \pm 1.8 \\
(0.7-8.5,2)^{*}\end{array}$ & $\begin{array}{c}\mathrm{I} \pm 0.7 \\
(0.4-2.6,0.8)^{*}\end{array}$ \\
\hline Retinal hemorrhage $(-)$ & $\begin{array}{c}20 \pm 34 \\
(0.1-138,7.5)\end{array}$ & $\begin{array}{c}3.2 \pm 2.3 \\
(0.8-10.5,2.7)\end{array}$ & $\begin{array}{c}1.7 \pm 1.1 \\
(0.5-5,1.5)\end{array}$ & $\begin{array}{c}0.7 \pm 0.5 \\
(0.2-2.6,0.6)\end{array}$ \\
\hline Retinal tear $(+)$ & $\begin{array}{c}60 \pm 166 \\
(0.4-806,8.3)\end{array}$ & $\begin{array}{c}3.7 \pm 3.4 \\
(I-15,2.7)\end{array}$ & $\begin{array}{c}2.1 \pm 1.9 \\
(0.6-8.5,1.9)\end{array}$ & $\begin{array}{c}0.8 \pm 0.6 \\
(0.2-2.6,0.6)\end{array}$ \\
\hline Retinal tear $(-)$ & $\begin{array}{c}35 \pm 56 \\
(0.1-269,9.8)\end{array}$ & $\begin{array}{c}3.6 \pm 3.6 \\
(0.8-19.7,2.6)\end{array}$ & $\begin{array}{c}2 \pm 1.2 \\
(0.5-5,1.8)\end{array}$ & $\begin{array}{c}0.9 \pm 0.7 \\
(0.2-2.6,0.8)\end{array}$ \\
\hline Retinal detachment $(+)$ & $\begin{array}{c}|2| \pm \mid 15 \\
(I-269,|1| 4)^{*}\end{array}$ & $\begin{array}{c}7 \pm 7 \\
(1.1-19.7,3.4)\end{array}$ & $\begin{array}{c}3.3 \pm 2.7 \\
(0.7-8.5,2.5)\end{array}$ & $\begin{array}{c}I .4 \pm 1 \\
(0.3-2.6,0.8)\end{array}$ \\
\hline Retinal detachment $(-)$ & $\begin{array}{c}36 \pm 114 \\
(0.1-806,9.4)\end{array}$ & $\begin{array}{c}3.2 \pm 2.3 \\
(0.8-13,2.6)\end{array}$ & $\begin{array}{c}1.9 \pm 1.2 \\
(0.5-7.5,1.8)\end{array}$ & $\begin{array}{c}0.8 \pm 0.6 \\
(0.2-2.6,0.7)\end{array}$ \\
\hline Uveal prolapse (+) & $\begin{array}{c}106 \pm 214 \\
(6-806,34.7)^{*}\end{array}$ & $\begin{array}{c}4.4 \pm 3.4 \\
(1.8-13.2,3)\end{array}$ & $\begin{array}{c}3 \pm 1.8 \\
(1.7-7.5,2)^{*}\end{array}$ & $\begin{array}{c}1.4 \pm 0.8 \\
(0.5-2.6,1.2)^{*}\end{array}$ \\
\hline Uveal prolapse (-) & $\begin{array}{c}29 \pm 60 \\
(0.1-269,6.7)\end{array}$ & $\begin{array}{c}3.4 \pm 3.4 \\
(0.8-19.7,2.6)\end{array}$ & $\begin{array}{c}1.8 \pm 1.3 \\
(1.5-8.5,1.5)\end{array}$ & $\begin{array}{c}0.7 \pm 0.5 \\
(0.2-2.6,0.5)\end{array}$ \\
\hline \multicolumn{5}{|l|}{ Complications } \\
\hline Glaucoma $(+)$ & $\begin{array}{c}1 \mathrm{II} \pm 252 \\
(2-806,9.4)\end{array}$ & $\begin{array}{c}3.6 \pm 3.5 \\
(1.5-13.2,2.5)\end{array}$ & $\begin{array}{c}2.3 \pm 2 \\
(0.7-8.5,1.7)\end{array}$ & $\begin{array}{c}I \pm 0.8 \\
(0.4-2.6,0.6)\end{array}$ \\
\hline Glaucoma (-) & $\begin{array}{c}33 \pm 56 \\
(0.1-269,9.7)\end{array}$ & $\begin{array}{c}3.6 \pm 3.5 \\
(0.8-19.7,2.7)\end{array}$ & $\begin{array}{c}2 \pm 1.4 \\
(0.5-8.5,1.8)\end{array}$ & $\begin{array}{c}0.9 \pm 0.6 \\
(0.2-2.6,0.7)\end{array}$ \\
\hline Recurrence/new RD (+) & $\begin{array}{c}|I| \pm 24 \mid \\
(0.2-806,9.5)\end{array}$ & $\begin{array}{c}4.8 \pm 4.8 \\
(1.1-15,2.7)\end{array}$ & $\begin{array}{c}2.8 \pm 2.6 \\
(0.7-8.5,2)\end{array}$ & $\begin{array}{c}0.8 \pm 0.7 \\
(0.3-2.5,0.5)\end{array}$ \\
\hline Recurrence/new RD (-) & $\begin{array}{c}3 I \pm 54 \\
(0.1-269,9.6)\end{array}$ & $\begin{array}{c}3.3 \pm 3 \\
(0.8-19.7,2.6)\end{array}$ & $\begin{array}{c}1.9 \pm 1 \\
(0.5-5,1.8)\end{array}$ & $\begin{array}{c}0.9 \pm 0.6 \\
(0.2-2.6,0.7)\end{array}$ \\
\hline \multicolumn{5}{|l|}{ Surgical management } \\
\hline PPV after primary globe repair & $\begin{array}{c}46 \pm 68 \\
(4-269,21)\end{array}$ & $\begin{array}{c}4.2 \pm 4.2 \\
(2-19.7,3)\end{array}$ & $\begin{array}{c}2.4 \pm 1.2 \\
(0.7-5,2.3)\end{array}$ & $\begin{array}{c}I . I \pm 0.6 \\
(0.4-2.6,0.9)\end{array}$ \\
\hline Combined primary globe repair and PPV & $\begin{array}{c}77 \pm 168 \\
(1-806,15.5)\end{array}$ & $\begin{array}{c}4.1 \pm 3.6 \\
(1.1-15,2.8)\end{array}$ & $\begin{array}{c}2.5 \pm 1.9 \\
(0.9-8.5,2)\end{array}$ & $\begin{array}{c}I . I \pm 0.7 \\
(0.3-2.6,0.7)\end{array}$ \\
\hline PPV as a single procedure (self-sealing wound) & $\begin{array}{c}6 \pm 10 \\
(0.1-44,2.6)^{*}\end{array}$ & $\begin{array}{c}2.5 \pm 2.1 \\
(0.8-10.5,2)^{*}\end{array}$ & $\begin{array}{c}1.2 \pm 0.5 \\
(0.5-2,1.1)^{*}\end{array}$ & $\begin{array}{c}0.5 \pm 0.2 \\
(0.2-I, 0.4)^{*}\end{array}$ \\
\hline
\end{tabular}

RD: Retinal detachment; PPV: Pars plana vitrectomy; ${ }^{p} p<0.05$ with Mann-Whitney U Test. 
Table 3. Correlation between BCVA and intraocular foreign body size

\begin{tabular}{lcccc}
\hline Visual acuity & Weight & Width & Length & Thickness \\
\hline Initial best corrected visual acuity & $r s=0.435 p=0.00 I^{*}$ & $r s=0.370 p=0.004^{*}$ & $r s=0.357 p=0.006^{*}$ & $r s=0.434 p=0.00 I^{*}$ \\
Final best corrected visual acuity & $r s=0.396 p=0.002^{*}$ & $r s=0.278 p=0.034^{*}$ & $r s=0.361 p=0.005^{*}$ & $r s=0.326 p=0.012^{*}$ \\
\hline
\end{tabular}

"Statistical significance by Spearman's correlation.

Table 4. Association between prognostic factors and visual acuity

\begin{tabular}{lcc}
\hline Prognostic factors & Initial best corrected visual acuity (p) & Final best corrected visual acuity $(\mathbf{p})$ \\
\hline Nature of IOFBs & $=0.773$ & $=0.364$ \\
Removal time (delayed or not) & Not-evaluated & $=0.919$ \\
Removal site (sclera or trans-corneal) & $=0.056$ & $=0.163$ \\
Localization of intraocular foreign body & $=0.740$ & $=0.684$ \\
Entry site (zone) of intraocular foreign body & $=0.281$ & $=0.097$ \\
Surgical management & $=0.456$ & $=0.904$ \\
Endophthalmitis & $=0.036^{*}$ & $=0.115$ \\
Iris injury & $=0.013^{*}$ & $=0.518$ \\
Lens injury & $=0.069$ & $=0.337$ \\
Hyphema & $=0.080$ & $=0.616$ \\
Vitreous hemorrhage & $=0.095$ & $=0.136$ \\
Retinal hemorrhage & $=0.009^{*}$ & $=0.094$ \\
Initial retinal detachment & $=0.092$ & $=0.045^{*}$ \\
Uveal prolapse & $=0.851$ & $=0.415$ \\
Recurrence/new retinal detachment & Not-evaluated & $=0.003^{*}$
\end{tabular}

BCVA: Best corrected visual acuity; 'The affect of surgical management groups (presented in table 3) on BCVA; "Statistical significance with Mann-Whitney U Test.

IOFBs (trans-corneal or sclera), initial findings, complications, and surgical management were evaluated (Mann-Whitney $U$ Test, Table 2). The weight of posterior segment IOFBs was significantly greater in eyes with initial hyphema, vitreous hemorrhage, retinal hemorrhage, retinal detachment, and uveal prolapse (Mann-Whitney $\cup$ Test, $p<0.001$, $p=0.021, p=0.048$, $p=0.049, p=0.002$, respectively). The length (longest diameter of an IOFB) of IOFBs was significantly longer in eyes with hyphema (Mann-Whitney $\cup$ Test, $p=0.024$ ). The width of IOFBs was significantly greater in eyes with initial hyphema, vitreous hemorrhage, retinal hemorrhage, and uveal prolapse (MannWhitney U Test, $p=0.003, p=0.022, p=0.048, p=0.003$, respectively). Thicker IOFBs were related to the presence of initial hyphema, vitreous hemorrhage, retinal hemorrhage, and uveal prolapse (Mann-Whitney $\cup$ Test, $p=0.00 \mathrm{I}, \mathrm{p}=0.024, \mathrm{p}=0.027$, $p=0.002$, respectively). There was a significant association between the removal site and thickness of IOFBs. Thicker IOFBs were removed through the trans-corneal rather than sclera (Mann-Whitney $U$ Test, $P=0.037$ ). Eyes with a self-sealing wound that underwent only PPV as the surgical management had lighter and smaller (length, width, and thickness) posterior segment IOFBs (Mann-Whitney U Test, $\mathrm{p}<0.05)$.
The presenting mean BCVA in decimal units was $0.25 \pm 0.28$ (logMAR, I.65 I.25; range, 20/20 to LP), and the final BCVA was $0.32 \pm 0.35$ (logMAR, 0.6I \pm 1.02 ; range, 20/20 to LP). The difference between initial and final BCVA was significant (Wilcoxon, $\mathrm{p}<0.00 \mathrm{I}$ ). Initial as well as final BCVA levels were negatively correlated with weight and dimensions (length, width, and thickness) of IOFBs (Spearman Correlation, Table 3). The relation between prognostic factors and BCVA indicated that presenting BCVA was poor in patients with initial endophthalmitis, lens injury, and retinal hemorrhage (Mann-Whitney $U$ Test, $p=0.036, p=0.013, p=0.009$, respectively) (Table 4). The presence of initial or subsequent (recurrent/new) retinal detachment was associated with poor final BCVA (Mann-Whitney $\cup$ Test, $\mathrm{p}=0.045, \mathrm{p}=0.003$, respectively). None of the other examined prognostic factors, including nature of IOFBs, entry points of IOFBs, removal time (delayed or not), removal site (sclera or trans-corneal), localization of IOFBs (retina or vitreous), surgical management, and initial findings, were statistically significant for either presenting or final BCVA (Table 4).

IOFBs were removed from the eyes within two days in 31 
eyes (53.4\%) and removed after two days in 27 eyes (46.6\%). Mean time to operation was $10.8 \pm 5$ days (range, 2-2I) in the latter group. The timing of IOFB removal was not associated with incidence of endophthalmitis or final BCVA (Mann-Whitney, $\mathrm{P}=0.055, \mathrm{P}=0.919$, respectively). Delaying IOFB removal was not associated with occurrence of retinal detachment or glaucoma (chi-square, $p=0.905, p=0.114$, respectively).

\section{DISCUSSION}

Advances in vitreoretinal instrumentation and surgical techniques have improved the success of treatment in open globe injuries with posterior segment IOFBs. The advantages of posterior segment IOFB removal using PPV include removal of vitreous to reduce the risk of retinal detachment, provides direct viewing and controlled surgery resulting in less collateral damage, and a possible reduced risk of endophthalmitis. ${ }^{[6-8]}$ We analyzed our population of patients with retained posterior segment IOFBs secondary to open globe injuries and evaluated the impact of IOFB-size and weight, prognostic factors, management, and outcomes.

In accordance with previous reports, vast majority of our patients were male ( $91 \%$ ) and relatively young (mean age, 32.7 years; median, 31 years). ${ }^{[1,2]}$ Their occupational injuries and a significant cause of ocular morbidity among, otherwise healthy, young males were preventable. This male predominance has been attributed to occupational exposure, dangerous sports and hobbies, alcohol use, and risk-taking behavior. [9-1I] In our population, the most common cause of injuries was work related $(67 \%)$, as in previous reports. ${ }^{[12-17]}$ Lack of eye protection was the major risk factor in this group as none of our patients were using protective eyewear at the time of injury. Metallic IOFBs have been reported in $60 \%$ to $91 \%$ of open globe injuries. ${ }^{[18-21]}$ Vast majority of posterior segment IOFBs in this study were metal $(90 \%)$.

The association between initial findings and size factors were evaluated. Greater weight, width, and thickness of the posterior segment IOFBs were associated with initial incidence of hyphema, vitreous hemorrhage, retinal hemorrhage, and uveal prolapse (Table 2). Heavier IOFBs were associated with the presence of initial retinal detachment and the length of posterior segment IOFBs was associated only with hyphema as a notable result. There was a significant association between the removal site and thickness of the IOFBs; thicker IOFBs were removed through the anterior chamber rather than the sclera.

To the best of our knowledge, this is the first study that correlates weight and size measurements of posterior segment IOFBs with presenting and final visual acuity levels. Several studies have investigated mass and size factors with grouped variables, and increased size of an IOFB has been a negative predictive factor for visual outcomes. ${ }^{[2,7]}$ Woodcock and col- leagues ${ }^{[21]}$ have concluded that a greater mass is associated with worse outcomes. In accordance with those studies, we found a significant negative correlation between weight, length, width, and thickness with presenting and final BCVA measurements.

In the management of IOFBs, these particles should be removed because of the risk for endophthalmitis and toxicity. However, timing of removal is controversial. ${ }^{[2,18,20-24]}$ The general consensus is that a delay in IOFB removal increases the risk for endophthalmitis. ${ }^{[24-29]}$ In contrast to this view, Colyer and colleagues ${ }^{[30]}$ have reported prompt wound closure and systemic antibiotics followed by delayed removal with no reported endophthalmitis. When we compared the groups that underwent IOFB removal within 48 hours (53\%) and IOFB removal after 48 hours (47\%) for initial incidence of endophthalmitis, there was no significant difference. The latter group had prompt primary globe repair with systemic antibiotics and underwent PPV in 10 days. We believe that delays in IOFB removal may be necessary in patients with corneal edema, severe inflammation, and intact posterior hyaloid as this combination prevents controlled surgery. $A$ current study by Falavarjani and colleagues ${ }^{[3 !]}$ has reported high anatomical success despite a delay in surgery. Therefore, we recommend the removal of posterior segment IOFBs at the most appropriate time rather than initial intervention.

Retinal detachment is an important prognostic factor for anatomical success in ocular injuries with posterior segment IOFBs. In our population, the most common complication after posterior segment IOFB removal was retinal detachment (18.9\%). Retinal detachment, initial or subsequent, was associated with poor final BCVA. Glaucoma was the second most frequent complication (I7.2\%) in this population. Although most of the eyes responded to medical therapy, one patient underwent glaucoma surgery. The incidence of retinal detachment and glaucoma did not increase in the group with delayed vitrectomy. We could not provide anatomical integrity in two (3.4\%) eyes because of the large entry site. Postoperative long-term hypotony resulted in phthisis bulbi in these eyes.

A limitation of this study is the lack of further correlations between velocity of IOFBs and study parameters due to the retrospective design of study. Moreover, the velocity of an IOFB is not only associated with the degree of tissue damage but also attributed to be conversely correlated with the risk of endophthalmitis. Thus, additional studies to investigate the association of these factors are required.

In conclusion, weight and dimensions of posterior segment IOFBs are significant predictive factors for visual outcomes in open globe injuries treated with vitrectomy. Heavier IOFBs have a risk of initial retinal detachment. Retinal detachment, initial or subsequent, was an important prognostic factor for 
poor final visual acuity. In this study, endophthalmitis and other complications were not related to delayed vitrectomy. Therefore, a delay in IOFB removal after prompt primary globe repair may be an advisable option while waiting for optimal surgical conditions.

\section{Conflict of interest: None declared.}

\section{REFERENCES}

1. Ehlers JP, Kunimoto DY, Ittoop S, Maguire JI, Ho AC, Regillo CD. Metallic intraocular foreign bodies: characteristics, interventions, and prognostic factors for visual outcome and globe survival. Am J Ophthalmol 2008;146:427-433. CrossRef

2. Zhang $Y$, Zhang M, Jiang C, Qiu HY. Intraocular foreign bodies in china: clinical characteristics, prognostic factors, and visual outcomes in 1,421 eyes. Am J Ophthalmol 2011;152:66-73. CrossRef

3. Potts AM, Distler JA. Shape factor in the penetration of intraocular foreign bodies. Am J Ophthalmol 1985;100:183-7. CrossRef

4. Kuhn F, Morris R, Witherspoon CD. Birmingham Eye Trauma Terminology (BETT): terminology and classification of mechanical eye injuries. Ophthalmol Clin North Am 2002;15:139-43. CrossRef

5. Pieramici DJ, Sternberg P Jr, Aaberg TM Sr, Bridges WZ Jr, Capone A $\mathrm{Jr}$, Cardillo JA, et al. A system for classifying mechanical injuries of the eye (globe). The Ocular Trauma Classification Group. Am J Ophthalmol 1997;123:820-31. CrossRef

6. Chow DR, Garretson BR, Kuczynski B, Williams GA, Margherio R, Cox MS, et al. External versus internal approach to the removal of metallic intraocular foreign bodies. Retina 2000;20:364-9. CrossRef

7. Wani VB, Al-Ajmi M, Thalib L, Azad RV, Abul M, Al-Ghanim M, et al. Vitrectomy for posterior segment intraocular foreign bodies: visual results and prognostic factors. Retina 2003;23:654-60. CrossRef

8. Mieler WF, Ellis MK, Williams DF, Han DP. Retained intraocular foreign bodies and endophthalmitis. Ophthalmology 1990;97:1532-8. CrossRef

9. McCarty CA, Fu CL, Taylor HR. Epidemiology of ocular trauma in Australia. Ophthalmology 1999;106:1847-52. CrossRef

10. Koo L, Kapadia MK, Singh RP, Sheridan R, Hatton MP. Gender differences in etiology and outcome of open globe injuries. J Trauma 2005;59:175-8. CrossRef

11. George J, Ali N, Rahman NA, Joshi N. Spectrum of intra-ocular foreign bodies and the outcome of their management in Brunei Darussalam. Int Ophthalmol 2013;33:277-84. CrossRef

12. Jafari AK, Anvari F, Ameri A, Bozorgui S, Shahverdi N. Epidemiology and sociodemographic aspects of ocular traumatic injuries in Iran. Int Ophthalmol 2010;30:691-6. CrossRef

13. Chang CH, Chen CL, Ho CK, Lai YH, Hu RC, Yen YL. Hospitalized eye injury in a large industrial city of South-Eastern Asia. Graefes Arch Clin Exp Ophthalmol 2008;246:223-8. CrossRef

14. Thompson GJ, Mollan SP. Occupational eye injuries: a continuing prob- lem. Occup Med (Lond) 2009;59:123-5. CrossRef

15. Mansouri M, Faghihi H, Hajizadeh F, Rasoulinejad SA, Rajabi MT, Tabatabaey A, et al. Epidemiology of open-globe injuries in Iran: analysis of 2,340 cases in 5 years (report no. 1). Retina 2009;29:1141-9. CrossRef

16. Bauza AM, Emami P, Son JH, Langer P, Zarbin M, Bhagat N. Workrelated open-globe injuries: demographics and clinical characteristics. Eur J Ophthalmol 2013;23:242-8. CrossRef

17. Lit ES, Young LH. Anterior and posterior segment intraocular foreign bodies. Int Ophthalmol Clin 2002 Summer;42:107-20. CrossRef

18. Parke DW 3rd, Pathengay A, Flynn HW Jr, Albini T, Schwartz SG. Risk factors for endophthalmitis and retinal detachment with retained intraocular foreign bodies. J Ophthalmol 2012;2012:758526.

19. Camacho H, Mejía LF. Extraction of intraocular foreign bodies by pars plana vitrectomy. A retrospective study. Ophthalmologica 1991;202:1739. CrossRef

20. Parke DW 3rd, Flynn HW Jr, Fisher YL. Management of intraocular foreign bodies: a clinical flight plan. Can J Ophthalmol 2013;48:8-12.

21. Woodcock MG, Scott RA, Huntbach J, Kirkby GR. Mass and shape as factors in intraocular foreign body injuries. Ophthalmology 2006;113:2262-9. CrossRef

22. Andreoli CM, Andreoli MT, Kloek CE, Ahuero AE, Vavvas D, Durand ML. Low rate of endophthalmitis in a large series of open globe injuries. Am J Ophthalmol 2009;147:601-8. CrossRef

23. Thompson JT, Parver LM, Enger CL, Mieler WF, Liggett PE. Infectious endophthalmitis after penetrating injuries with retained intraocular foreign bodies. National Eye Trauma System. Ophthalmology 1993;100:1468-74. CrossRef

24. Ahmed Y, Schimel AM, Pathengay A, Colyer MH, Flynn HW Jr. Endophthalmitis following open-globe injuries. Eye (Lond) 2012;26:212-7.

25. Bhagat N, Nagori S, Zarbin M. Post-traumatic Infectious Endophthalmitis. Surv Ophthalmol 2011;56:214-51. CrossRef

26. Alfaro DV, Roth D, Liggett PE. Posttraumatic endophthalmitis. Causative organisms, treatment, and prevention. Retina 1994;14:206-11.

27. Essex RW, Yi Q, Charles PG, Allen PJ. Post-traumatic endophthalmitis. Ophthalmology 2004;111:2015-22. CrossRef

28. Duch-Samper AM, Menezo JL, Hurtado-Sarrió M. Endophthalmitis following penetrating eye injuries. Acta Ophthalmol Scand 1997;75:104-6.

29. Chaudhry IA, Shamsi FA, Al-Harthi E, Al-Theeb A, Elzaridi E, Riley FC. Incidence and visual outcome of endophthalmitis associated with intraocular foreign bodies. Graefes Arch Clin Exp Ophthalmol 2008;246:181-6. CrossRef

30. Colyer MH, Weber ED, Weichel ED, Dick JS, Bower KS, Ward TP, et al. Delayed intraocular foreign body removal without endophthalmitis during Operations Iraqi Freedom and Enduring Freedom. Ophthalmology 2007;114:1439-47. CrossRef

31. Falavarjani KG, Hashemi M, Modarres M, Parvaresh MM, Naseripour $\mathrm{M}, \mathrm{Nazari} \mathrm{H}$, et al. Vitrectomy for posterior segment intraocular foreign bodies, visual and anatomical outcomes. Middle East Afr J Ophthalmol 2013;20:244-7. CrossRef 
ORİJINAL ÇALIŞMA - ÖZET

\section{Arka segment göz içi yabancı cisimleri: A ğırlık ve boyut etkisi, erken veya geç vitrektomi ve sonuçlar \\ Dr. Zafer Öztaş, ${ }^{1}$ Dr. Serhad Nalçacı, ${ }^{1}$ Dr. Filiz Afrashi, ${ }^{1}$ Dr. Tansu Erakgün, ${ }^{2}$ \\ Dr. Jale Menteş, ${ }^{1}$ Dr. Cumali Değirmenci, ${ }^{1}$ Dr. Cezmi Akkın ${ }^{1}$}

${ }^{1}$ Ege Üniversitesi Tıp Fakültesi, Göz Hastalıkları Anabilim Dalı, İzmir

${ }^{2}$ Ekol Kulak Burun Boğaz Hastanesi, Göz Hastalıkları Kliniği, İzmir

AMAÇ: Arka segment göz içi yabancı cisim (GiYC) ağılık ve boyut özelliklerinin açık glob yaralanmalarındaki etkilerini belirlemek.

GEREÇ VE YÖNTEM: Çalışmaya arka segment GiYC bulunan 58 hastanın 58 gözü dahil edildi. Tüm GiYC'ler pars plana vitrektomi ile çıkarıldı. Yaş, cins, en iyi düzeltilmiş görme keskinliği (EiDGK), GiYC niteliği, ağılığı ve çapları, başlangıçtaki göz bulguları, GiYC çıkarılma zamanı, GiYC giriş alanı, yapılan müdaheleler ve komplikasyonları içeren faktörler incelendi.

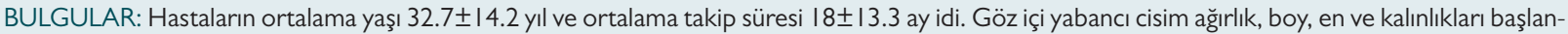
gıç ve final EIDGK seviyeleri ile negatif korele bulundu $(p<0.05)$. Başlangıçta hifema, vitreus hemorajisi, retina hemorajisi, retina dekolmanı ve üveal prolapsus bulunan olgulardaki GiYC'ler önemli ölçüde daha ağır bulundu $(p<0.05)$. Hifema, vitreus hemorajisi, retina hemorajisi, retina dekolmanı ve üveal prolapsus bulunan olgulardaki GiYC'ler önemli ölçüde daha enli ve kalın bulundu $(p<0.05)$. Hifemalı gözlerdeki GiYC'ler anlamlı olarak daha uzun bulundu $(p<0.05)$. Başlangıçta veya daha sonra retina dekolmanının olması düşük final görme ile ilşkili bulundu $(p<0.05)$. Göz içi yabancı cisim çıkarılma zamanı ile endoftalmi insidansı arasında ilişki yoktu.

TARTIŞMA: Daha ağır ve büyük arka segment GiYC'leri ile birlikte olan açık glob yaralanmaları daha kötü sonuçlara ilişkilidir. İş kazalarından korunmak için koruyucu gözlük kullanımı kritik bir öneme sahiptir. Bizim çalışmamızda GiYC'nin erken veya geç çıkarımasının anatomik ve görsel sonuçlar üzerine önemli bir etkisi saptanmamıştır. Bu nedenle uygun koşullar elde edilene kadar vitrektomi ertelenebilir.

Anahtar sözcükler: Endoftalmi; göz içi yabancı cisimleri; pars plana vitrektomi; retina dekolmanı.

Ulus Travma Acil Cerrahi Derg 2015;2I(6):496-502 doi: 10.5505/tjtes.2015.03608 